\title{
Synthetic Seed Preparation, Germination and Plantlet Regeneration of Litchi (Litchi chinensis Sonn.)
}

\author{
D. K. Das*, A. Rahman, Dipti Kumari, Nutan Kumari \\ Post Graduate Department of Biotechnology, T.M. Bhagalpur University, Bhagalpur, India \\ Email: *dilipdas1@live.com
}

Received 5 March 2016; accepted 19 July 2016; published 22 July 2016

Copyright (C) 2016 by authors and Scientific Research Publishing Inc.

This work is licensed under the Creative Commons Attribution International License (CC BY). http://creativecommons.org/licenses/by/4.0/

(c) (i) Open Access

\section{Abstract}

Litchi (Litchi chinensis sonn.) ranks second after mango amongst the most important fruit crops cultivated worldwide. Litchi is a very valuable crop throughout the world because it is a table fruit and wines are also produced from it. The existing cultivars are highly polyploidy and heterozygous in nature. It is propagated through air layering and marcottage methods and storability is very low. Synthetic seeds can be stored for a long time and its genetic constitution could remain the same. For germplasm maintenance and clonal propagation, synthetic seeds can be used. Somatic embryogenesis has been reported from anther or embryogenic suspension culture in various species of litchi. Regeneration via organogenesis and somatic embryogenesis from zygotic embryos has also been reported in certain species. Developing a methodology for getting somatic embryogenesis with a high frequency from zygotic embryos which is available once in a year, would be particularly useful for genetic improvement of litchi. Cotyledonary stage somatic embryos developed from zygotic embryos were encapsulated in $2 \%$ alginate gel. The encapsulated somatic embryos (ESEs) germinated successfully on $0.7 \%$ agar medium containing $3 \%$ sucrose concentration in NN basal medium (half strength of major and minor salts) with $1 \mathrm{mg} \cdot \mathrm{l}^{-1}$ of gibbrellic acid. Percentage germination and plantlet development for ESEs was higher than that of non encapsulated embryos (NSEs). In comparison to different hormones, gibberellic acid has a significant influence on the germination rate of ESEs after one week of dehydration was seen maximum at $9 \%$ sucrose and abscisic acid (1 mg.l-1) in half strength of major and minor salts in Nitsch and Nitsch medium resulting in extended storage up to 90 days without loss in germination potential and capability to regenerate into plantlets. Normally developed plantlets regenerated from ESEs were successfully adapted to soil to obtain a full grown plant.

${ }^{*}$ Corresponding author.

How to cite this paper: Das, D.K., Rahman, A., Kumari, D. and Kumari, N. (2016) Synthetic Seed Preparation, Germination and Plantlet Regeneration of Litchi (Litchi chinensis Sonn.). American Journal of Plant Sciences, 7, 1395-1406.

http://dx.doi.org/10.4236/ajps.2016.710133 


\section{Keywords}

\section{Encapsulation, Germination, Plantlet Regeneration, Somatic Embryos}

\section{Introduction}

Litchi (Litchi chinensis Sonn.) of the family Sapindaceae is tropical tree known for its delicious fruits. It is extensively grown in tropical and subtropical regions of the world, especially in India and China. Since litchi is a cross pollinated plant, it is highly heterozygous, and the progeny may not true to the parental type. Conventional vegetative propagation methods currently being used air layering or marcottage, are slow and inefficient [1]. Natural seeds contain high percentage of moisture which is protected by the enveloping aril. As soon as aril is removed the moisture content decreases and seeds lost the ability of germination. Both germinability and viability is correlated with moisture content. These seeds can't be stored at room temperature due to high moisture content and if these seeds remain exposed in air for one day after separation from aril, seeds will loose germinability due to loose of moisture content and unable to regenerate into litchi plants and many varieties also produce non viable seeds so natural system is not suited for plant regeneration. In litchi moisture content range is $50 \%$ $60 \%$ [2]. In Urd bean moisture content is reported to come down to $12 \%$ [3]. In sesame moisture content has been found to be inversely related to seed longevity [4]. Loss of viability of onion seeds increased with increase in moisture content from $4 \%$ to $40 \%$ [5]. Seeds stored at $5 \%$ or less moisture content possess better chance of viability [6]. Hence in vitro techniques have potential use in litchi propagation for the large-scale cloning of elite plants. Litchi (Litchi chinensis Sonn.) is the most important fruit crop second to Mango and cultivated most of the parts of the world. However, litchi has so far proven to be a difficult material for propagation using in vitro culture. Attempts to regenerate plants from explants derived from mature trees have failed to give satisfactory results [7]. However, the formation of up to 15 adventitious buds was reported when immature litchi zygotic embryos were treated with BAP $\left(100 \mathrm{mg} \cdot \mathrm{l}^{-1}\right)$ for $3 \mathrm{~h}$ followed by culture on hormone free MS medium for 4 weeks [8] and 15 - 20 multiple shoots were also induced from matured zygotic embryos (from seeds) also produced when treated with BAP $\left(20 \mathrm{mg} \cdot l^{-1}\right)$ and litchi plantlets were also regenerated [9]. For a rapid clonal multiplication and for the genetic improvement of litchis several groups have reported somatic embryogenesis in litchi cultivars like grapes [10]-[29]. Green fluorescent protein gene has been expressed in litchi tissues [30] and protocol for litchi transformation has also been developed [29]. Long-term storage of clones in the form of cuttings often encountered the problem of infection. Therefore, in order to circumvent these problems development of synthetic seeds appears to be a better alternative. An important application of somatic embryos is their use in the production of synthetic seeds [16]. Encapsulation of embryos is the first major step for synthetic seed production in litchi. Alginate gel capsules provide protection for naked somatic embryos (NSEs) and facilitate handling [31]-[34]. Artificial seed technology provides an alternative system for propagation of transgenic plants, non seed producing plants, polyploids with elite traits and plants with problems in seed propagation. The technology may also be of interest for storage of germplasm and transportation of elite genotypes. The synthetic seed technology is best suited for the maintenance of genetic constitution of regenerated plants and can be stored for a long time. The application of synthetic seed technology has been demonstrated for many plant species [34]-[38] and the role of abscisic acid (ABA) is implicated as a controlling factor for germination and dormancy in somatic embryos and seeds [39] [40].

In this paper we demonstrate the development and utility of artificial seeds in seedless or functionless seeds of litchi varieties. We have also studied the effect of ABA on germination and plantlet regeneration from encapsulated somatic embryos. We have encapsulated 4 - $9 \mathrm{~mm}$ long immature cotyledonary stage somatic embryos (originating from immature zygotic embryos of cv Bedana), as mature somatic embryos are longer than $2.5 \mathrm{~cm}$ and difficult to encapsulate. We report the parameters for the production of somatic embryos in litchi, their encapsulation, germination and regeneration into plantlets.

\section{Materials and Methods}

\subsection{Production of Somatic Embryos}

Zygotic embryos isolated from immaturelitchi (Litchi chinensis Sonn.) fruits were obtained from the Horticul- 
ture Division, Bihar Agricultural College, Sabour, Bhagalpur, INDIA. Primary somatic embryos were induced from zygotic embryos which were pre-soaked in citric acid $\left(2 \mathrm{~g} \cdot \mathrm{l}^{-1}\right)$ for $1 \mathrm{~h}$ and then cultured on MS1 medium consisted of MS [41] salts and B5 [42] vitamins with 2, 4-D (2 mg. $\left.\mathrm{l}^{-1}\right), 50 \mathrm{~g} \cdot \mathrm{l}^{-1}$ sucrose, and also supplemented with $2 \mathrm{~g} \cdot \mathrm{l}^{-1}$ Ascorbic acid and $3 \mathrm{~g} \cdot \mathrm{l}^{-1}$ Citric acid and $8 \mathrm{~g} \cdot \mathrm{l}^{-1}$ agar (pH 5.8). Repetitive somatic embryos occurs if primary somatic embryos were cultured on NN basal medium supplemented with IBA $\left(0.1 \mathrm{mg} \cdot \mathrm{l}^{-1}\right)$ led to formation of embryogenic calli which upon sub culturing on fresh NN [43] basal medium differentiated into a large number of secondary somatic embryos as mentioned in the protocol of [34]. At the cotyledonary stage, somatic embryos were white opaque in appearance 4 - $9 \mathrm{~mm}$ long embryos harvested and used for encapsulation. The composition of $\mathrm{NN}$ basal medium is

\begin{tabular}{|c|c|}
\hline Constituents & Concentration (mg/l) \\
\hline \multicolumn{2}{|l|}{ Macronutrient } \\
\hline $\mathrm{MgSO}_{4} \cdot 7 \mathrm{H}_{2} \mathrm{O}$ & 185 \\
\hline $\mathrm{KH}_{2} \mathrm{PO}_{4}$ & 68 \\
\hline $\mathrm{KNO}_{3}$ & 950 \\
\hline $\mathrm{NH}_{4} \mathrm{NO}_{3}$ & 720 \\
\hline \multicolumn{2}{|l|}{ Micronutrient } \\
\hline $\mathrm{MnSO}_{4} \cdot 4 \mathrm{H}_{2} \mathrm{O}$ & 25 \\
\hline $\mathrm{ZnSO}_{4} \cdot 7 \mathrm{H}_{2} \mathrm{O}$ & 10 \\
\hline $\mathrm{Na}_{2} \mathrm{MoO}_{4} \cdot 2 \mathrm{H}_{2} \mathrm{O}$ & 0.25 \\
\hline $\mathrm{CuSO}_{4} \cdot 5 \mathrm{H}_{2} \mathrm{O}$ & 0.025 \\
\hline $\mathrm{CoCl}_{2} \cdot 6 \mathrm{H}_{2} \mathrm{O}$ & 0.025 \\
\hline \multicolumn{2}{|l|}{ Iron Source } \\
\hline $\mathrm{FeSO}_{4} \cdot 7 \mathrm{H}_{2} \mathrm{O}$ & 27.8 \\
\hline $\mathrm{Na}_{2}$. EDTA & 37.3 \\
\hline \multicolumn{2}{|l|}{ Vitamin Source } \\
\hline Thiamine hydrochloride & 0.5 \\
\hline Pyridoxine hydrochloride & 0.5 \\
\hline Nicotinic acid & 5.0 \\
\hline Glycine & 2.0 \\
\hline myoinocitol & 100 \\
\hline Sucrose & $30 \times 10^{3}$ \\
\hline $\mathrm{pH}$ & 5.7 \\
\hline Difco bacto-agar & 8000.0 \\
\hline
\end{tabular}

MS1 medium consisted of MS salts and B5 vitamins with 2, 4-D (2 mg: $\left.\mathrm{l}^{-1}\right), 50 \mathrm{~g} \cdot \mathrm{l}^{-1}$ sucrose, and also supplemented with $2 \mathrm{~g} \cdot \mathrm{l}^{-1}$ Ascorbic acid and $3 \mathrm{~g} \cdot \mathrm{l}^{-1}$ Citric acid and $8 \mathrm{~g} \cdot \mathrm{l}^{-1}$ agar (pH 5.8).

\subsection{Encapsulation of Somatic Embryos}

To encapsulate somatic embryos in calcium alginate capsules, a $2 \%$ sodium alginate (Sigma) gel (prepared in a nutrient solution containing one quarter strength of B5 macrosalts and MS organics) and $100 \mathrm{mM} \mathrm{CaCl}_{2}$ solution (in double distilled water) were used. For encapsulation isolated somatic embryos from embryogenic calli were suspended in $2 \%$ sodium alginate solution for $2 \mathrm{~min}$ and then dropped one by one through a Pasture pipette into $\mathrm{CaCl}_{2}$ solution kept on a low speed Vortex mixer (about $100 \mathrm{rpm}$ ). The resulting beads were kept for 40 - 45 min for hardening. The Gel i.e. Calcium alginate is formed by the reaction between Sodium alginate and calcium chloride. This reaction makes the gel polymerized and hardening starts from 30min and completes in $45 \mathrm{~min}$ around somatic embryos. Encapsulated embryos were washed with sterile distilled water for 5 min to remove remnants of $\mathrm{CaCl}_{2}$ from the surface of capsules. All the steps for encapsulation were done under aseptic conditions.

\subsection{Germination and Plantlet Development from ESEs}

The effect of sucrose and ABA on germination of somatic embryos was assessed. For each treatment, 6 petri disces (each with either ESEs orNSEs) sealed with parafilm were maintained in a 16 h photoperiod (60 $\mu \mathrm{mol} \cdot \mathrm{m}^{-2} \cdot \mathrm{s}^{-1}$ light intensity) at $25^{\circ} \mathrm{C} \pm 2^{\circ} \mathrm{C}$. The number of dead, arrested (remaining green without showing any activity at the radicular or plumular end and germinating (showing emergence of tap root and shoot meristem) somatic embryos were counted for each treatment after 6 weeks in the first and second experiments. The per- 
centage of dead, arrested, and germinating somatic embryos was calculated against the total number of encapsulated (401) and non-encapsulated (505) somatic embryos cultured. Number of embryos for each treatment ranged from 66 to 87 with a mean value of 76.5 for encapsulated embryos and 78 to 115 with a mean of 96.5 non-encapsulated embryos. Each experiment repeated three times.

Subsequently, the germinating somatic embryos (5 per flask) were transferred to 250 ml Erlenmeyer flasks, each with $50 \mathrm{ml}$ liquid medium containing half-strength B5 macrosalts with full-strength MS microsalts, ironEDTA and organics, $2.74 \mathrm{mM}$ L-glutamine (added before $\mathrm{pH}$ adjustment) and 3\% (w/v) sucrose. Glutamine is known to play a regulatory as well as a nutritive role in somatic embryo maturation and during autoclaving it is converted to 5-oxoproline [44]. The cultures were maintained in a $16 \mathrm{~h}$ photoperiod as described earlier. After 6 - 8 weeks the elongated somatic embryos were cultured on MS basal semi-solid (0.7\% agar) medium for complete development of plants and percentage of plantlets was calculated for each treatment in each of the experiments.

\subsection{Establishment of Plantlets in Soil}

Normally developed plantlets with roots were transferred to plastic pots containing moistened agro peat soil and kept in artificial light $\left(60 \mu \mathrm{mol} \cdot \mathrm{m}^{-2} \cdot \mathrm{s}^{-1}\right.$ light intensity provided by cool white fluorescent tubes) at a temperature ranging between $25^{\circ} \mathrm{C}$ and $30^{\circ} \mathrm{C}$. The plantlets were initially covered with polythene bags to maintain humidity and were irrigated with tap water. After $20 \mathrm{~d}$, the pots were transferred initially to sunlight for a short duration (30 mm). This period was gradually increased and polythene bags were removed. The plants were transferred to garden soil in clay pots after 3 - 4 months and kept outdoor under natural light conditions.

\subsection{Storage of Somatic Embryos in Synthetic Seeds}

The embryogenic calli were cultured in different concentrations of sucrose (2, 3, 6, 9\%) with ABA (0.004, 0.02, $0.04,0.2,0.4 \mu \mathrm{M})$ for 4 - 6 weeks followed by encapsulation of somatic embryos as described above. The synthetic seeds were kept in a bottle at room temperature up to three months. After storage, the synthetic seeds were cultured on NN or MS basal medium supplemented with $2.9 \mu \mathrm{M} \mathrm{GA}$ for checking their viability and germination.

\section{Results and Discussion}

Primary somatic embryos were generated from zygotic embryos when cultured on MS1 medium, they were subcultured on either NN basal or NN medium supplemented with IBA and within 4 - 6 weeks embryogenic callus was formed (Figure 1(a)), which differentiated into many globular to cotyledonary stage secondary embryos. The globular stage somatic embryos reached the cotyledonary stage in 4 weeks (Figure 1(b)). The cotyledons (closed) of most of the somatic embryos became opaque and milky-white in colour (Figure 1(c)) to light-green or green after transfer to light.

\subsection{Germination and Plantlet Development from ESEs}

For germination of encapsulated (Figure $1(\mathbf{d})$ ) or naked white, opaque, cotyledonary-stage somatic embryos were cultured on MS agar medium containing B5 macrosalts, MS microsalts, iron EDTA, organics with 3\% sucrose and $0.7 \%$ agar supplemented with $2.9 \mu \mathrm{M} \mathrm{GA}_{3}$. During germination, both ESEs and NSEs turned lightgreen or green within a week of inoculation on agar medium. Germination was initiated with the emergence of tap roots (Figure 1(e)). Roots from ESEs became visible within 1 - 2 weeks of culture on agar medium, whereas root initiation from NSEs became visible only after 2 weeks of culture in the same medium. Further root elongation and proliferation of leaves from shoot meristem were observed only after transfer to MS liquid medium containing glutamine. Roots continued to grow up to 5 - $10 \mathrm{~cm}$ within 3 weeks of culture before shoot emergence (Figure 1(f)). The shoot elongation of such rooted embryos became visible within 2 - 3 weeks by the development of small leaves (Figure 1(g), Figure 1(h)). The proliferation of shoot meristems, enlargement of leaves and formation of plantlets (Figure 1(i)) were observed only after 4 - 6 weeks of culture on MS basal semi-solid medium. In this way, both NSEs and ESEs developed into complete plantlets and there were no differences in the morphology of plantlets raised from ESEs and NSEs. However, after 4 - 6 weeks of culture, percent germination and plantlet development from ESEs was higher than that of NSEs (Table 1). NSES with ar- 


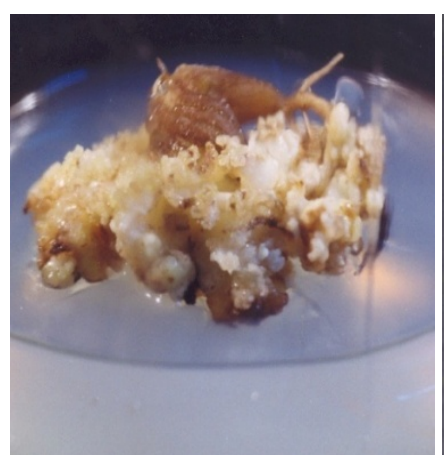

(a)

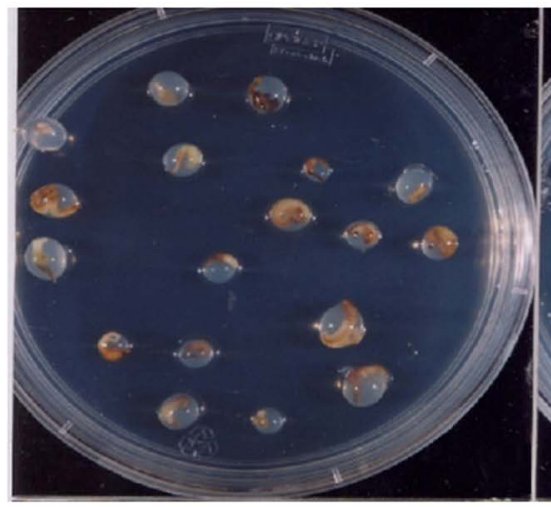

(d)

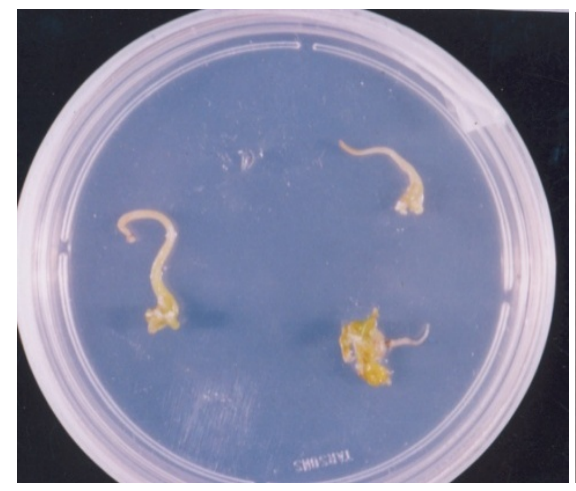

(g)

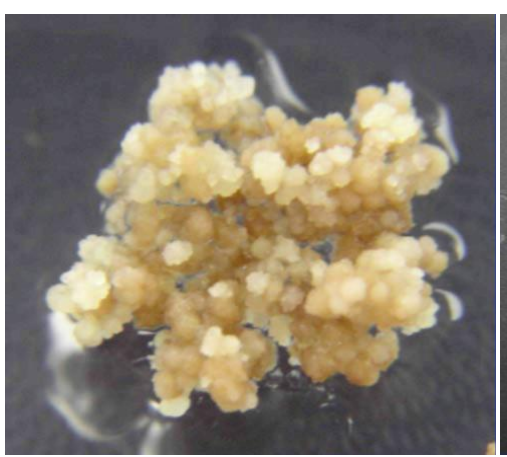

(b)

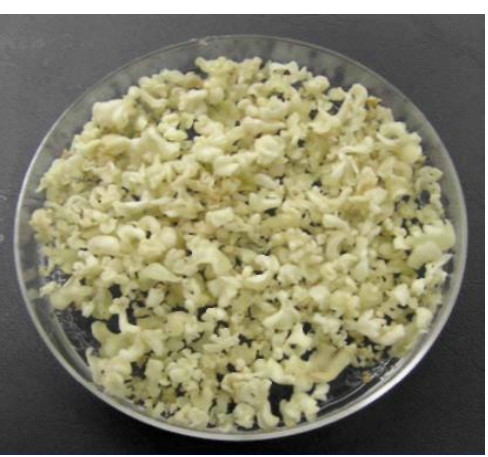

(c)

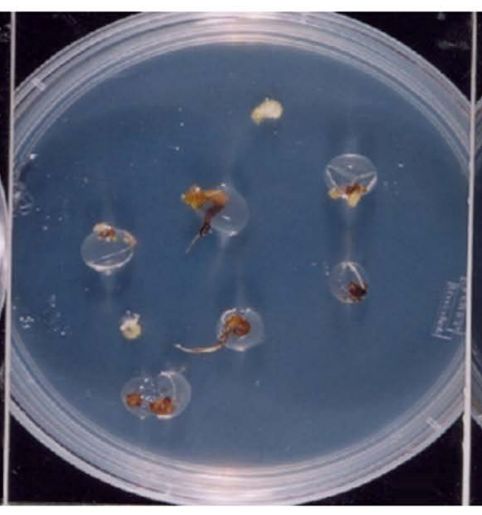

(e)

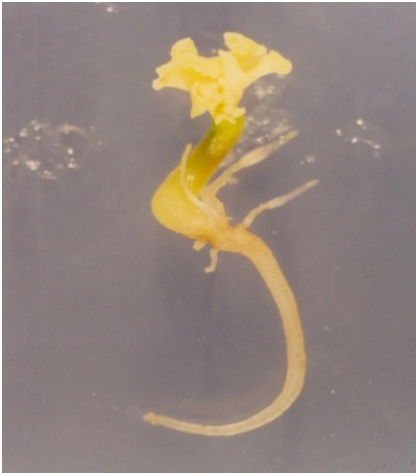

(h)

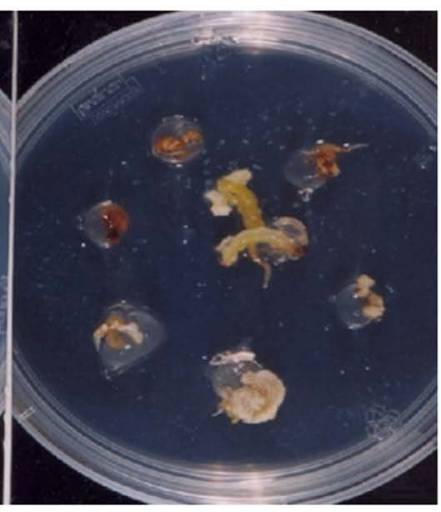

(f)

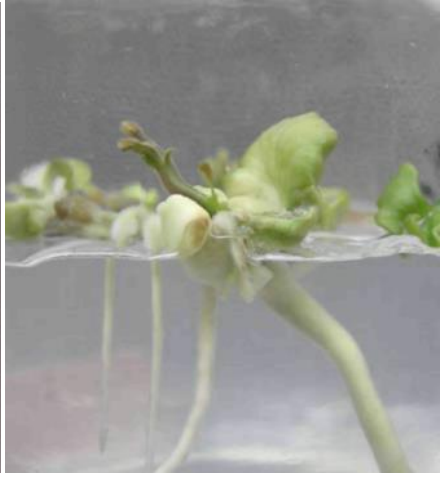

(i)

Figure 1. Encapsulation and germination of somatic embryos of litchi (Litchi chinensis Sonn.). (a) Embryogenic calli originated from zygotic embryos of cultivar Bedana; (b) globular somatic embryos differentiated from embryogenic calli; (c) cotyledonary stage somatic embryos; (d) encapsulation of somatic embryos; (e) germinating ESEs showing emergence of root; (f) emergence of shoot meristem at the tip of elongated somatic embryo; (g) in somatic embryos roots are elongated in liquid medium; (h)-(i) development of sturdy root and shoot systems in semi-solid medium.

Table 1. Response of NSEs and ESEs on agar medium**.

\begin{tabular}{cccccc}
\hline Exp. No. & $\begin{array}{c}\text { Conditions of somatic } \\
\text { embryos }\end{array}$ & Germination (\%) & Dead (\%) & $\begin{array}{c}\text { Arrested } \\
\text { germination (\%) }\end{array}$ & Plantlets (\%) \\
\hline 1 & NSEs & $23.7 \pm 3.7$ & $30.0 \pm 6.5$ & $44.1 \pm 3.1$ & $8.0 \pm 1.6$ \\
2 & ESEs & $44.3 \pm 4.5$ & $18.0 \pm 3.8$ & $17.2 \pm 4.3$ & $16.0 \pm 1.6$ \\
\hline
\end{tabular}

"Mean value of three independent experiments $\pm \mathrm{SE}$ and petri plates are in triplicate in each experiment. 
rested germination showed cotyledon growth up to 2 weeks of culture in liquid medium and no growth was observed on semi-solid medium. A lower percentage of dead embryos were observed in ESEs than NSEs (Table 2). The reason for this may be attributed the protection provided by capsules as well as the presence of nutrients in the gel matrix which apparently served as a nutrient bed around the somatic embryos. This facilitated growth and survival and allowed embryos to germinate as described by [31] [32]. Our observations with litchi are more or less similar to grape and mango [38] but in contrast to those reported for Santalum album [35], Solanum melongena [45] and Asparagus cooperi [46], for which the frequency of germinating ESEs was lower than that of NSEs. In all these examples, however, mature somatic embryos were used in encapsulation. The production of synthetic seeds for the first time by [47] involved encapsulation of carrot somatic embryos followed by their desiccation. Of the various compounds tested for encapsulation of celery embryos, [48] selected polyoxyethylene which is readily soluble in water and dries to form a thin film, does not support the growth of micro-organisms and is non-toxic to the embryo. [49] has reported that desiccated artificial seeds were produced by coating a mixture of carrot somatic embryos and callus in polyoxyethylene glycol. The coating mixture was allowed to dry for several hours on a Teflon surface in a sterile hood. The dried mixture was then placed on culture medium, allowed to rehydrate, and then scored for embryo survival. Development of artificial seeds requires sufficient control of somatic embryogeny from the explants to embryo production, embryo development and their maturation as well. The mature somatic embryos must be capable of germinating out of the capsule or coating to form vigorous normal plants. A number of researchers have tried to improve the quality [50]-[53] and quantity [54]-[56] of somatic embryos via modification of culture conditions, such as, medium composition, growth regulators (types and concentrations), physical state of the medium, as well as incubation conditions like temperature, illumination, etc. Although large quantities of somatic embryos can be rapidly produced in many plant species, normal plants are difficult to obtain due to their improper or asynchronous maturation. Hence, maturation of somatic embryos, which eventually controls germination and conversion rate, is one of the major bottlenecks for synthetic seed production. While studying the effects of different types of osmotica on maturation of somatic embryos of spruce, [51] and [57] have described that inclusion of high levels Encapsulation Synthetic seed development Storage Plant development Greenhouse and field planting of sucrose (i.e. permeating osmotica) in the standard medium containing ABA (which is associated with water stress), prevents maturation while inclusion of PEG (non-permeating osmotica) with ABA dramatically improves the frequency and synchrony of the somatic embryo maturation. To achieve conversion of somatic embryos into plantlets and to overcome deleterious effects of recurrent somatic embryogenesis as well as anomalous development of somatic embryos on their conversion, it is necessary to provide optimum nutritive and environmental conditions [55] [58]. Maltose has been found valuable for improving alfalfa somatic embryo conversion [31]. From a synthetic seed perspective, addition of sucrose in the medium is necessary for viability of somatic embryos, their subsequent development, maturation and germination in many plant species [52] [55] [59]. In an in vitro culture system the somatic embryos show great diversity in their morphology and accordingly in their response which greatly limits the use of synthetic seed technology.

\subsection{Effect of Concentration of B5 Macrosalts on Germination and Plantlet Development from ESEs}

The strength of B5 macrosalts in the agar medium affected significantly the percent ESEs germination the highest percentage was observed in medium supplemented with quarter strength B5 macrosalts. The ratio of germination to conversion into plantlets increased in the B5 macrosalts, MS microsalts, iron EDTA, organics and 3\%

Table 2. Influence of B5 macrosalt on germination and plantlet development*.

\begin{tabular}{ccccc}
\hline Exp No. & Concentration of macro salts & Germination (G) (\%) & Conversion (C) of plants (\%) & G/C \\
\hline 1. & Full strength & 10.0 & 6.64 & 1.49 \\
2. & Half strength & 21.7 & 13.0 & 1.55 \\
3. & Quarter strength & 69.1 & 36.0 & 1.91 \\
4. & One eighth strength & 35.7 & 24.3 & 1.46 \\
\hline
\end{tabular}

\footnotetext{
*Values are mean of three independent experiments \pm SE.
} 
sucrose supplemented with $2.9 \mu \mathrm{M} \mathrm{GA}_{3}$ (Table 2). It is suspected that the morphological development of somatic embryos is regulated by endogenous hormones [60]. [61] have described the effect of anti-auxins on polar auxin transport which controls embryo development. For initiation of the two cotyledons, a polar auxin transport in the embryo is needed for a short period during the globular stage and developmental abnormalities occur due to cell divisions in the meristematic areas prior to differentiation of the shoot apex and cotyledons [60] [61].

\subsection{Effect of ABA on Germination and Plantlet Development from ESEs}

In general, ESEs (no ABA treatment) started germination after 1 - 2 weeks of culture, whereas ABA-treated ESEs showed germination after 3 - 4 weeks irrespective of the ABA concentration. However, ABA concentration affected the percent response (Table 3). ESEs treated with 0.004 or $0.02 \mu \mathrm{M}$ ABA showed a slight decrease in percent germination and plantlet development relative to the control, but the decrease was not significant (Table 4). The ESEs treated with higher concentrations $(0.04,0.2$ or $0.4 \mu \mathrm{M})$ of ABA showed a significant difference in percent response in comparison with the control, with a large number of ESEs either dying or showing arrested germination (Table 3). With increasing ABA concentration (0.04 to $0.2 \mu \mathrm{M})$, percent germination and conversion into plantlets decreased gradually, and no ESEs germinated if they were treated with $0.4 \mu \mathrm{M}$ ABA Table 3). [62] have indicated that continuous ABA treatment increases the formation of somatic embryos with anomalous cotyledons, while in some instances ABA has been found to promote the normal development of both somatic and zygotic embryos in vitro [63] [64]. Cytokinin treatment also increases the number of somatic embryos with multiple cotyledons [65].

It is evident from the results that ABA at lower concentrations ( 0.03 or $0.02 \mu \mathrm{M})$ had no influence on embryo germination or conversion into plantlets although it caused a delay of up to 3 - 4 weeks in germination (recorded on MS medium containing B5 macrosalts, MS microsalts, MS iron-EDTA, MS organics and 3\% sucrose supplemented with $2.9 \mu \mathrm{M} \mathrm{GA}_{3}$ ). Inhibition of germination was significant when the ESEs were treated with higher concentrations (0.04, 0.2 and $0.4 \mu \mathrm{M}$ ) of ABA. Exogenous ABA treatment prevented precocious germination of immature somatic embryos in several species [33] [46].

Table 3. Responses of ABA-treated and non-treated ESEs on agar medium*.

\begin{tabular}{cccccc}
\hline Exp. No. & $\begin{array}{c}\text { Concentrations of } \\
\text { ABA }(\boldsymbol{\mu M})\end{array}$ & Germination (\%) & Dead (\%) & $\begin{array}{c}\text { Arrested germination } \\
(\%)\end{array}$ & Plantlet (\%) \\
\hline 1 & 0.0 & $78.0 \pm 3.1$ & $17.5 \pm 1.7$ & $4.0 \pm 1.6$ & $42.1 \pm 1.9$ \\
2 & 0.004 & $72.0 \pm 2.1$ & $20.5 \pm 1.1$ & $5.5 \pm 1.1$ & $39.1 \pm 1.9$ \\
3 & 0.02 & $69.8 \pm 3.0$ & $20.5 \pm 2.9$ & $6.1 \pm 1.5$ & $36.1 \pm 3.4$ \\
4 & 0.04 & $23.3 \pm 3.2$ & $31.3 \pm 2.3$ & $39.5 \pm 2.1$ & $12.2 \pm 1.1$ \\
5 & 0.2 & $8.0 \pm 1.6$ & $41.5 \pm 2.3$ & $38.5 \pm 1.1$ & $3.0 \pm 1.6$ \\
6 & 0.4 & 0 & $64.7 \pm 1.5$ & $40.0 \pm 1.6$ & 0 \\
\hline
\end{tabular}

*Mean values of three independent experiments \pm SE. P value is 0.0337.

Table 4. Effect of sucrose with or without ABA in NN basal medium on the survival of somatic embryos after 4 - 6 weeks of culture.

\begin{tabular}{|c|c|c|c|}
\hline \multirow[t]{3}{*}{ Exp. No. } & \multirow{3}{*}{$\begin{array}{c}\text { Sucrose concentration } \\
(\%)\end{array}$} & \multicolumn{2}{|c|}{ Survival of somatic embryos } \\
\hline & & \multicolumn{2}{|c|}{$(\%)$} \\
\hline & & Without ABA & With ABA \\
\hline 1 & 1.0 & 5 & 7.0 \\
\hline 2 & 3.0 & 15 & 56.7 \\
\hline 3 & 6.0 & 30 & 46.7 \\
\hline 4 & 9.0 & 61 & 92.3 \\
\hline
\end{tabular}




\subsection{Effect of Sucrose and ABA on Survival of Somatic Embryos}

Germination and survival of somatic embryos were assessed in the medium containing different concentrations of sucrose with or without ABA. At lower concentrations of sucrose (1\% - 3\%) embryos remained hydrated and started germination without any delay. As the concentration of sucrose was increased to 6 or $9 \%$, the embryos became more and more dehydrated. If the somatic embryos were first encapsulated and then cultured for 4 - 6 weeks in medium containing $9 \%$ sucrose and ABA, the synthetic seeds remained viable at least up to three months at room temperature (Table 4). Survival of somatic embryos in synthetic seeds was checked through germination on MS medium containing B5 macrosalts, MS microsalts, iron-EDTA, organics with 3\% sucrose and $0.7 \%$ agar supplemented with $2.9 \mu \mathrm{M} \mathrm{GA}_{3}$.The developmental anomalies, however, are not intrinsic to somatic embryos, because immature zygotic embryos can also exhibit similar irregularities when removed from the seed and allowed to develop in vitro. [60] have suggested that unbalanced endogenous hormone distribution by exogenous hormone treatment may result in the abnormal somatic embryos. In many plant species the somatic embryos have been found to be sensitive to desiccation. Desiccation damages the somatic embryos and inhibits their germination and conversion into plants in desiccation-sensitive plant species [31] [32].

\subsection{Transfer of Plantlets to Soil}

In the first two weeks after adaptation to soil, the plantlets showed no further development. After two weeks, some plantlets showed blackening at the shoot tips, and died gradually. However, plantlets, which did not exhibit the symptoms, survived and grew in agropeat (Figure 2(a)). Growth was initially very slow. Out of 20 plantlets, 15 reached an age of 4 months in field soil (Figure 2(b)). The plantlets obtained from ESEs and NSEs were transferred into the field and no marked difference in their growth was observed. Transfer of plants to soil, obtained from somatic embryos of litchi cultivars has been done. Desiccation damages the somatic embryos and inhibits their germination and conversion into plants in desiccation-sensitive plant species [31] [32]. Nevertheless, desiccation and subsequent rehydration have been found useful in inducing a high frequency conversion of somatic embryos into plantlets in some species [66] [67]. Gradual drying of alfalfa somatic embryos with progressive and linear loss of water gave better response and improved the quality of embryos in comparison to uncontrolled drying [31]. Similarly, desiccation improved the germination frequency in soybean [68] also [39] have reported that desiccation tolerance can be induced in somatic embryos of alfalfa by external stimuli such as ABA, exposure to cold, heat, water and osmotic stress at sub-lethal levels or increasing the sucrose content in the medium. [53] and [60] have reported that somatic embryos of spruce matured in the presence of PEG and ABA were very tolerant to low moisture levels. According to them, such somatic embryos had less than $50 \%$ moisture content which was further reduced to less than $10 \%$ following desiccation. These embryos were stored at $-200 \mathrm{C}$ for a year and thereafter successfully germinated following imbibition with no loss in viability. The coating material may also limit success of the synthetic seed technology, and at present none of the embryo encapsulation methods described earlier is completely satisfactory.

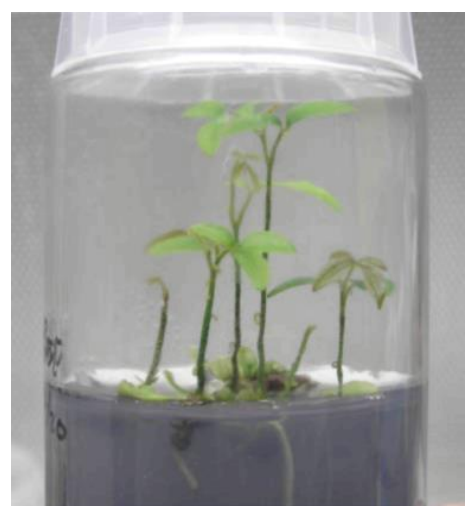

(a)

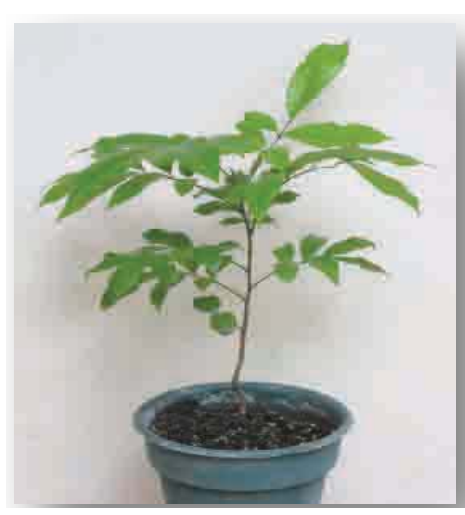

(b)

Figure 2. In vitro grown plants transferred to field soil. (a) In vitro grown litchi plantlets in semi solid medium; (b) acclimatized in vitro litchi plantlets were transferred into field soil. 


\section{Conclusion}

Our study demonstrates successful plant regenerated from in vitro raised somatic embryos encapsulated in calcium alginate. The synthetic embryos are capable to germinate and regenerate into plants. The main advantage of encapsulated embryos will probably be their use as an alternative for long-term storage and mass propagation of planting material. Thus, it is expected that with further refinement of the techniques for production of somatic embryos, synthetic seeds will be used in litchi biotechnology.

\section{Acknowledgements}

Financial assistance provided by the University Grants Commission, New Delhi is gratefully acknowledged.

\section{References}

[1] Chapman, K.R. (1984) Sapindaceae. Lychae. In: Page, P.E, Ed., Tropical Tree Fruits for Australia, Queensland Department of Primary Industries, Brisbane, 179-191.

[2] Das, D.K. (1988) Studies on Carbohydrate Metabolism Associated with Seed Development and Germination of Litchi and Water Chestnut. Ph.D. Thesis, Bhagalpur University, Bhagalpur.

[3] Sah, A. (1987) Physiology of Seed Development in Urd Bean. Indian Journal of Plant Physiology, 30, 199-201.

[4] Ellis, R.H., Hong, T.D. and Roberts, E.H. (1986) Logarithmic Relationship between Moisture Content and Longevity Sesame Seeds. Annals of Botany, 57, 499-503.

[5] Agrawal, P.K., Dadlani, M. and Kumari, G.V. (1988) Viability of Onion Seeds: Storage with Low and High Seed Moisture. Plant Physiology and Biochemistry, 15, 97-106.

[6] Mackey, D.B. and Flood, R.J. (1968) Investigations in Crop Seed Longevity II. The Viability of Cereal Stored in Permeable and Impermeable Containers. Journal of the National Institute of Agricultural Botany, 11, 378-403.

[7] Kantharajah, A.S., Dodd, W.A. and McConchie, C.A. (1989) The Possible Contribution of Tissue Culture to the Lychee Industry. Proceedings of the Second National Lychee Seminar, Cairns, 59-65.

[8] Kantharajah, A.S., Dodd, W.A. and Mc Conchie, C.A. (1992) In Vitro Embryo Culture and Induction of Multiple Shoots in Lychee (Litchi chinensis Sonn.), Ann. Botany, 70, 153-156.

[9] Das, D.K., Shiva Prakash, N. and Sarin, N.B. (1999) Multiple Shoots Induction and Plant Regeneration in Litchi (Litchi chinensis Sonn.). Plant Cell Reports, 18, 691-695. http://dx.doi.org/10.1007/s002990050644

[10] Yu, C.H., Chen, Z.G., Lu. L.X. and Lin. J.W. (2000) Somatic Embryogenesis and Plant Regeneration from Litchi Protoplasts Isolated from Embryogenic Suspensions. Plant Cell Tissue Organ Culture, 61, 51-58. http://dx.doi.org/10.1023/A:1006446506041

[11] Puchooa, D. (2004) In Vitro Regeneration of Lychee (Litchi chinensis Sonn.). African Journal of Biotechnology, 3, 576-584.

[12] Mullins, M.G. and Srinivasan, C. (1976) Somatic Embryos and Plantlets from an Ancient Clone of the Grapevine (cv. Cabernet-Sauvignon) by Apomixes in Vitro. Journal of Experimental Botany, 27, 1022-1030. http://dx.doi.org/10.1093/jxb/27.5.1022

[13] Reish, B.I. and Roberts, M.H. (1985) Embryogenesis from Petiole Cultures of Horizon Grapes. Proc 4th Int. Symp. Grapevine Breeding, Verona, 32-33.

[14] Gray, D.J. and Mortensen, J.A. (1987) Initiation and Maintenance of Long Term Somatic Embryogenesis from Anthers and Ovaries of Vitis longii “Microsperma”. Plant Cell Tissue Organ Culture, 9, 73-80. http://dx.doi.org/10.1007/BF00046081

[15] Hirabayashi, T. (1985) Somatic Embryogenesis Leaf Tissues of Grape. In: Coll. Amelior. Vigne Cult. In Vitro, 75-82, Paris.

[16] Merkle, S.A., Paott, W.A. and Williams, E.G. (1990) Applications of Somatic Embryogenesis and Embryo Cloning. In: Bhojwani, S.S., Ed., Plant Tissue Culture: Applications and Limitations, Elsevier, Amsterdam, 67-101. http://dx.doi.org/10.1016/B978-0-444-88883-9.50008-X

[17] Martinelli, l., Gianazza, E. and Villa, P.L. (1991) Somatic Embryogenesis from Leaves and Petioles of Grapevines. Acta Horticulture, 289, 243-244. http://dx.doi.org/10.17660/ActaHortic.1991.289.63

[18] Martinelli, L., Bragagna, P., Poletti, V. and Scienza, A. (1993) Somatic Embryogenesis Leaf and Petiole Derived Callus of Vitis rupestris. Plant Cell Reports, 12, 207-210. http://dx.doi.org/10.1007/BF00237055

[19] Mezzotint, B., Pandolfini, T., Navacchi, O. and Landi, L. (2002) Genetictransformation of Vitis vinifera via Organo- 
genesis. BMC Biotechnology, 2, 1. http://dx.doi.org/10.1186/1472-6750-2-1

[20] Mullins, M.G., Archie, T.F.C. and Facclotti, D. (1990) Agrobacterium Mediated Genetic Transformation of Grapevine: Transgenic Plants of Vitis rupestris Scheele and Buds of Vitis vinifera L. Biotechnology, 8, 1041-1045. http://dx.doi.org/10.1038/nbt1190-1041

[21] Perl, A., Lotan, O., Abu-Abied, M. and Holland, D. (1996) Establishment of an Agrobacterium-Mediated Transformation System for Grape (Vitis vinifera L.): The Role of Antioxidants during Grape-Agrobacterium Interactions. Nature Biotechnology, 14, 15-21. http://dx.doi.org/10.1038/nbt0596-624

[22] Robacker, C. (1993) Somatic Embryogenesis and Plant Regeneration from Muscadine Grape Leaf Explants. Horticultural Science, 28, 53-55.

[23] Salunckhe, C.K., Rao, P.S. and Mhatre, M. (1997) Induction of Somatic Embryogenesis and Plantlets in Tendrils of Vitis vinifera L. Plant Cell Reports, 17, 65-67. http://dx.doi.org/10.1007/s002990050353

[24] Salunkhe, C.K., Rao, P.S. and Mhatre, M. (1999) Plantlet Regeneration via Somatic Embryogenesis in Anther Callus of Vitis latifolia L. Plant Cell Reports, 18, 670-673. http://dx.doi.org/10.1007/s002990050640

[25] Raharjo, S.H.T. and Litz, R.E. (2004) Clonal Regeneration of Litchi (Litchi chinensis Sonn.) via Somatic Embryogenesis. International Symposium on Biotechnology of Temperate Fruit Crops and Tropical Species, Daytona Beach, 10-14 October 2005, 127.

[26] Scorza, R., Cordts, J.M., Gray, D.J., Gonsalves, D., Emershad, R.L. and Ramming, D.W. (1996) Producing Transgenic “Thomson Seedless" Grape (Vitis vinifera L.) Plants. Journal of American Society of Horticulture Science, 121, 616619.

[27] Das, D.K., Reddy, M.K., Upadhyaya, K.C. and Sopory, S.K. (2002) An Efficient Leaf Disc Culture Method for the Regeneration via Somatic Embryogenesis and Transformation of Grape (Vitis vinifera L.) Plant Cell Reports, 20, 9991005. http://dx.doi.org/10.1007/s00299-002-0441-4

[28] Das, D.K., Reddy, M.K., Upadhyay, K.C. and Sopory, S.K. (2005) Grape (Vitis vinifera L.). In: Jain S.M. and Gupta P.K., Eds., Protocol for Somatic Embryogenesis in Woody Plants, Sringer, Netherlands, 301-308. http://dx.doi.org/10.1007/1-4020-2985-3 24

[29] Das, D.K. and Rahman, A. (2013) Induction of Somatic Embryogenesis and Long Term Maintenance of Embryogenic Lines of Litchi. Current Trends of Biotechnology and Pharmacy, 7, 625-634.

[30] Puchooa, D. (2004) Expression of Green Fluorescent Protein Gene in Litchi (Litchi chinensis Sonn.) Tissues. Journal of Applied Horticulture, 6, 11-15.

[31] Redenbaugh, K. and Walker, K. (1990) Role of Artificial Seeds in Alfalfa Breeding. In: Bhojwani, S.S., Ed., Plant Tissue Culture: Applications and Limitations, Developments, Crop Science, 19, Elsevier, Amsterdam, 102-135. http://dx.doi.org/10.1016/b978-0-444-88883-9.50009-1

[32] Redenbaugh, K., Slade, D., Viss, P. and Fujii, J. (1993) Hydrated Coatings for Synthetic Seeds. In: Redenbaugh, K., Ed., Synseeds: Application of Synthetic Seeds to Crop Improvement, CRC, Boca Raton, 35-46.

[33] Attree, S.M., Pomeroy, M.K. and Fowke, L.C. (1994) Production of Vigorous, Desiccation Tolerant White Spruce (Picea glauca Moench Voss.) Synthetic Seeds in a Bioreactor. Plant Cell Reports, 13, 601-606. http://dx.doi.org/10.1007/BF00232929

[34] Das, D.K., Nirala, N.K., Reddy, M.K., Sopory, S.K. and Upadhyaya, K.C. (2006) Encapsulated Somatic Embryos of Grape (Vitis vinifera L.): An Efficient Way for Storage and Propagation of Pathogen-Free Plant Material. Vitis, 45, 179-184

[35] Bapat, V.A. and Rao, P.S. (1988) Sandalwood Plantlets from Synthetic Seeds. Plant Cell Reports, 7, 434-436.

[36] Padmaja, G., Reddy, L.R. and Reddy, G.M. (1995) Plant Regeneration from Synthetic Seeds of Groundnut, Arachis hypogea L.. Indian Journal of Experimental Biology, 33, 967-971.

[37] Onay, A., Jeffree, C.E. and Yeoman, M.M. (1996) Plant Regeneration from Encapsulated Embryoids and an Embryonic Mass of Pistachio, Pistacia vera L. Plant Cell Reports, 15, 723-726. http://dx.doi.org/10.1007/BF00231933

[38] Ara, H., Jaiswal, U. and Jaiswal, V.S. (1999) Germination and Plantlet Regeneration from Encapsulated Somatic Embryos of Mango (Mangifera indica L.). Plant Cell Reports, 19, 166-170. http://dx.doi.org/10.1007/s002990050728

[39] Senaratna, T., Saxena, P.K., Rao, M.V. and John, A. (1995) Significance of the Zygotic Seed Coat on Quiescence and Desiccation Tolerance of Medicago sativa L. Somatic Embryos. Plant Cell Reports, 14, 375-379. http://dx.doi.org/10.1007/BF00238600

[40] Bewley, J.D. (1997) Seed Germination and Dormancy. Plant Cell, 9, 1055-1066. http://dx.doi.org/10.1105/tpc.9.7.1055

[41] Murashige, T. and Skoog, F. (1962) A Revised Medium for Rapid Growth and Bioassays with Tobacco Tissue Cul- 
tures. Physiologia Plantarum, 15, 473-497. http://dx.doi.org/10.1111/j.1399-3054.1962.tb08052.x

[42] Gamborg, O.L., Miller, R.A. and Ojima, K. (1968) Nutrients Requirements of Suspension Cultures of Soybean Root Cells. Experimental Cell Research, 50, 151-158. http://dx.doi.org/10.1016/0014-4827(68)90403-5

[43] Nitsch, J.P. and Nitsch, C. (1969) Haploid Plants from Pollen Grains. Science, 163, 85-87. http://dx.doi.org/10.1126/science.163.3862.85

[44] Lal, R.B., Brodine, S. and Kazura, J. (1992) Sensitivity and Specificity of a Recombinant Transmembrane Glycoprotein (Rgp-21)-Spiked Western Immunoblot for Serological Confirmation of Human T-Cell Lymphotropic Virus Type I \& Type II. Journal of Clinical Microbiology, 30, 296-299.

[45] Lakshmana, P.V., Rao. P.V. and Singh, B. (1991) Plantlet Regeneration from Encapsulated Somatic Embryos of Hybrid Solanum melongena L. Plant Cell Reports, 10, 7-11. http://dx.doi.org/10.1007/bf00233023

[46] Ghosh, B. and Sen, S. (1994) Plant Regeneration from Alginate Encapsulated Somatic Embryos of Asparagus cooperi Rocker. Plant Cell Reports, 13, 381-385. http://dx.doi.org/10.1007/BF00234142

[47] Kitto, S.K. and Janick, J. (1985) Hardening Treatments Increase Survival of Synthetically Coated Asexual Embryos of Carrot. Journal of the American Society for Horticultural Science, 110, 283-286.

[48] Kitto, S.K. and Janick, J. (1982) Polyox as an Artificial Seed Coat for Asexual Embryos. Horticultural Science, 17, 488.

[49] Janick, J., Kim, Y.H., Kitto, S. and Saranga, Y. (1993) Desiccation Synthetic Seed. In: Redenbaugh, K., Ed., Synseed: Application of Synthetic Seeds to Crop Improvement, CRC Press Inc., Boca Raton, 11-33.

[50] Attree, S.M., Moore, D., Sawhney, V.K. and Fowke, L.C. (1991) Enhanced Maturation and Desiccation Tolerance of White Spruce [Picea glauca (Moench) Voss] Somatic Embryos: Effects of a Non-Plasmolysing Water Stress and Abscisic Acid. Annals of Botany, 68, 519-525.

[51] Attree, S. and Fowke, L. (1993) Embryogeny of Gymno-Sperms: Advances in Synthetic Seed Technology of Conifers. Plant Cell, Tissue and Organ Culture, 35, 1-35. http://dx.doi.org/10.1007/BF00043936

[52] Wetzstein, H.Y. and Baker, C.M. (1993) The Relationship between Somatic Embryo Morphology and Conversion in Peanut (Arachis hypogaea L.). Plant Science, 92, 81-89. http://dx.doi.org/10.1016/0168-9452(93)90068-B

[53] Attree, S.M., Pomeroy, M.K. and Fowke, L.C. (1995) Development of White Spruce [Picea glauca (Moench.) Voss] Somatic Embryos during Culture with Abscisic Acid and Osmoticum, and Their Tolerance to Drying and Frozen Storage. Journal of Experimental Botany, 46, 433-439. http://dx.doi.org/10.1093/jxb/46.4.433

[54] Michler, C.H. and Bauer, E.O. (1991) High Frequency Somatic Embryogenesis from Leaf Tissue of Populus spp. Plant Science, 77, 111-118. http://dx.doi.org/10.1016/0168-9452(91)90186-c

[55] Ara, H. (1998) Ph.D. Thesis, Banaras Hindu University, Varanasi.

[56] Burns, J.A. and Wetzstein, H.Y. (1997) Development and Characterization of Embryogenic Suspension Cultures of Pecan. Plant Cell, Tissue and Organ Culture, 48, 93-102. http://dx.doi.org/10.1023/A:1005832331593

[57] Fowke, L. and Attree, S. (1996) Conifer Somatic Embryogenesis-Studies of Embryo Development and the Cell Biology of Conifer Cells and Protoplasts. Plant Tissue Culture and Biotechnology, 2, 124-130.

[58] Capuano, M. and Debergh, P.C. (1997) Improvement of the Maturation and Germination of Horse Chestnut Somatic Embryos. Plant Cell, Tissue and Organ Culture, 48, 23-29. http://dx.doi.org/10.1023/A:1005890826431

[59] Jain, S.M., Gupta, P.K. and Netwon, R.J. (1995) Somatic Embryogenesis in Woody Plants. Kluwer Academic Publishers, Dordrecht, 145-181.

[60] Choi, Y.E., Kim, H.S., Soh, W.Y. and Yang, D.C. (1997) Development and Structural Aspects of Somatic Embryos Formed on Medium Containing 2,3,5-Triiodobenzoic Acid. Plant Cell Reports, 16, 738-744. http://dx.doi.org/10.1007/s002990050312

[61] Liu, C.M., Xu, Z.H. and Chua, N.H. (1993) Auxin Polar Transport Is Essential for the Establishment of Bilateral Symmetry during Early Plant Embryogenesis. Plant Cell, 5, 621-630. http://dx.doi.org/10.1105/tpc.5.6.621

[62] Lee, K.S. and Soh, W.Y. (1994) Effect of Abscisic Acid on the Number of Somatic Embryo Cotyledons in Tissue Cultures of Aralia cordata Thumb. Korean Journal of Plant Tissue Culture, 21, 287-291.

[63] Crouch, M.L. and Sussex, I.M. (1981) Abscisic Acid Promotes Accumulation of Storage Proteins in Cultured Embryos of Brassica napus L. Planta, 153, 64-74. http://dx.doi.org/10.1007/BF00385319

[64] Ammirato, P.V. (1983) Embryogenesis. In: Evans, D.A., Sharp, W.R., Ammirato, P.V. and Yamada, Y., Eds., Handbook of Plant Cell Culture, Vol. 1, Macmillan Publishing Co., New York, 82-123.

[65] Ammirato, P.V. (1977) Hormonal Control of Somatic Embryo Development from Cultured Cells of Caraway. Plant Physiology, 59, 579-586. http://dx.doi.org/10.1104/pp.59.4.579 
[66] Gray, D.J. (1987) Quiescenec in Monocotylenous Dicotyledonous Somatic Embryos Induced by Dehydration. Horticultural Science, 22, 810-814.

[67] Compton, M.E., Benton, C.M., Gray, D.J. and Songstad, D.D. (1992) Plant Recovery from Maize Somatic Embryos Subjected to Controlled Relative Humidity Dehydration. In Vitro Cellular \& Developmental Biology—Plant, 28, 197201. http://dx.doi.org/10.1007/BF02823317

[68] Hammatt, N. and Davey, M.R. (1987) Somatic Embryogenesis and Plant Regeneration from Cultured Zygotic Embryos of Soybean [Glycine max (L.) Merr.]. Journal of Plant Physiology, 128, 219-226. http://dx.doi.org/10.1016/S0176-1617(87)80235-3

\section{Abbreviations}

2, 4-D: 2, 4-dichlorophenoxyacetic acid

ABA: abscisic acid

$\mathrm{GA}_{3}$ : gibberellic acid

IBA: indole 3-butyric acid

MS medium: Murashige and Skoog (1962) medium

ESEs: encapsulated somatic embryos

NN medium: Nitsch and Nitsch (1969) medium

NSEs: non-encapsulated somatic embryos

B5 medium: Gamborg et al (1968) medium

EDTA: ethylene diamine tetra acetic acid

\section{Submit or recommend next manuscript to SCIRP and we will provide best service for you:}

Accepting pre-submission inquiries through Email, Facebook, LinkedIn, Twitter, etc.

A wide selection of journals (inclusive of 9 subjects, more than 200 journals)

Providing 24-hour high-quality service

User-friendly online submission system

Fair and swift peer-review system

Efficient typesetting and proofreading procedure

Display of the result of downloads and visits, as well as the number of cited articles

Maximum dissemination of your research work

Submit your manuscript at: http://papersubmission.scirp.org/ 